\title{
Effects of $\beta$-glucan polysaccharide revealed by the dominant lethal assay and micronucleus assays, and reproductive performance of male mice exposed to cyclophosphamide
}

\author{
Rodrigo Juliano Oliveira ${ }^{1,2,3}$, João Renato Pesarini ${ }^{1,2}$, Maria José Sparça Salles ${ }^{4}$, \\ Tatiane Yumi Nakamura Kanno ${ }^{4}$, Ana Carolina dos Santos Lourenço ${ }^{4}$, Véssia da Silva Leite ${ }^{4}$, \\ Ariane Fernanda da Silva ${ }^{4}$, Hevenilton José Matiazi ${ }^{5}$, Lúcia Regina Ribeiro ${ }^{6}$ and Mário Sérgio Mantovani ${ }^{4}$ \\ ${ }^{1}$ Centro de Estudos em Célula Tronco, Terapia Celular e Genética Toxicológica, Núcleo de Hospital \\ Universitário, Universidade Federal de Mato Grosso do Sul, Campo Grande, MS, Brazil. \\ ${ }^{2}$ Programa de Pós-Graduação em Saúde em Desenvolvimento na Região Centro-Oeste, Faculdade de \\ Medicina "Dr. Hélio Mandetta", Universidade Federal de Mato Grosso do Sul, Campo Grande,MS, Brazil. \\ ${ }^{3}$ Programa de Mestrado em Farmácia, Centro de Ciências Biológicas e da Saúde, \\ Universidade Federal de Mato Grosso do Sul, Campo Grande, MS, Brazil. \\ ${ }^{4}$ Departamento de Biologia Geral, Universidade Estadual de Londrina, Londrina, PR, Brazil. \\ ${ }^{5}$ Laboratório de Tecnologia em Alimentos e Medicamentos, Universidade Estadual de Londrina, \\ Londrina, PR, Brazil. \\ ${ }^{6}$ Programa de Pós-Graduação em Biologia Celular e Molecular, Instituto de Biociências, \\ Universidade Estadual Paulista “Júlio de Mesquita Filho”, Rio Claro, SP, Brazil.
}

\begin{abstract}
$\beta$-glucan is a well-known polysaccharide for its chemopreventive effect. This study aimed to evaluate the chemopreventive ability of $\beta$-glucan in somatic and germ cells through the dominant lethal and micronucleus assays, and its influence on the reproductive performance of male mice exposed to cyclophosphamide. The results indicate that $\beta$-glucan is capable of preventing changes in DNA in both germ cells and somatic ones. Changes in germ cells were evaluated by the dominant lethal assay and showed damage reduction percentages of $46.46 \%$ and $43.79 \%$ for the doses of 100 and $150 \mathrm{mg} / \mathrm{kg}$. For the somatic changes, evaluated by micronucleus assay in peripheral blood cells in the first week of treatment, damage reduction percentages from 80.63-116.32\% were found. In the fifth and sixth weeks, the percentage ranged from $10.20-52.54 \%$ and $-0.95-62.35 \%$, respectively. Besides the chemopreventive efficiency it appears that the $\beta$-glucan, when combined with cyclophosphamide, is able to improve the reproductive performance of males verified by the significant reduction in rates of post-implantation losses and reabsorption in the mating of nulliparous females with males treated with cyclophosphamide.
\end{abstract}

Key words: mutation, post-implantation losses, chemoprevention, micronucleus, nulliparous females.

Received: July 15, 2013; Accepted: November 13, 2013.

\section{Introduction}

Occupational exposure, exposure to environmental contaminants and therapeutic compounds are known to induce changes related to the development of infertility, cancer and abnormalities of offspring, amongst other factors (Anderson, 2005). For instance, studies over the last 50 years suggest a reduction of sperm count and volume of semen in fertile men due to increased pollution and chemicals

Send correspondence to Rodrigo Juliano Oliveira. Faculdade de Medicina, Universidade Federal do Mato Grosso do Sul, Cidade Universitária S/N, 79070-900 Campo Grande, MS, Brazil. E-mail: rodrigo.oliveira@ufms.br. used mainly in water treatment (Lipshultz and Fisch, 1992). Besides the prevalence of clinical causes of infertility (Ferrari, 1991), pharmacological agents, physical and chemical substances are also capable of modifying sperm quality (Van Thiel et al., 1979; De Cherney, 1987; Sadi, 1995; Orejuela and Lipshultz, 1998; Thonneau et al., 1998; Vested et al., 2013).

Among the causes reported for infertility, there is a correlation between the decline in fertility, abnormal sperm and the occurrence of changes in the offspring of men and/or experimental animals (Joffe and Soyka, 1984; Friedler, 1996; Oliveira et al., 2005). Generally, teratogenic tests are performed in pregnant females. However, as the 
male contributes half of the genetic information to the offspring, males can also be examined as partly responsible for teratogenesis and adverse changes in offspring development. Among these changes, smoking in men, for example, is is reported as related to the development of tumors in their children (Sorahan et al., 1997a,b; Ji et al., 1997; Sorahan et al., 2001; Pang et al., 2003; Cordier et al., 2004; Anderson, 2005). In addition, experiments indicate that the abuse of alcohol, administration of cyclophosphamide and sodium arsenite may also relate to changes in the offspring of parents where the males were exposed to the above xenobiotics (Jenkinson et al., 1987; Jenkinson and Anderson, 1990; Oliveira et al., 2005).

The dominant lethal assay is an important method for testing mutagenic substances (Shively et al., 1984). In this context, the presence of implantation sites that did not develop properly in females mated with males exposed to xenobiots is used as a criterion for success in insemination, and the fertility test is considered positive. If implants are not found, the result is negative (Sarkar et al., 2000). However, among the implants, the number of post-implantation losses is indicative of genomic damage that changes gene expression leading to embryonic and/or fetal death.

Identifying environmental substances that are capable of causing genomic damage is essential. Therefore, there is a growing interest in identifying natural and chemical compounds that are able to prevent genomic damage or alter reproductive performance. Among these compounds is $\beta$-glucan, a polysaccharide extracted mainly from fungi and cereals. This polysaccharide is known to be an important fiber with antimutagenic activity (Chorvatovicová et al., 1996, 1998; Slamenová et al., 2003; Tohamy et al., 2003; Lin et al., 2004; Oliveira et al., 2006, 2007, 2013; Angeli et al., 2006, 2009a,b; Mantovani et al., 2008; Silva et al., 2013), such as inulin (Mauro et al., 2013) and wheat (Pesarini et al., 2013). When extracted from yeast, it consists of D-glucose molecules linked in position $\beta$ - $(1 \rightarrow 3)$ containing side chains $\beta-(1 \rightarrow 6)$ (Di Luzio et al., 1979) with a great potential for producing drugs using biotechnology methods. Currently, this polysaccharide is described as an important antimutagenic agent, with ability to increase fetal viability and reduce the rates of post-implantation loss and/or resorption, thus demonstrating an improvement in the performance of reproductive females. However, this molecule showed no ability to prevent congenital malformations induced by cyclophosphamide (Oliveira et al., 2009b). Taken this fact into consideration, this study aimed to investigate the antimutagenic activity of $\beta$-glucan, extracted from Saccharomyces cerevisiae in somatic cells of mice by means of the micronucleus assay in peripheral blood cell. In addition, the potential for preventing damage in germ cells was evaluated through the dominant lethal assay and the influence of $\beta$-glucan on the reproductive performance of male mice exposed to cyclophosphamide was investigated.

\section{Material and Methods}

\section{DNA damage-inducing agent}

The alkylating agent cyclophosphamide (Fosfaseron ${ }^{\circledR}$ ) was diluted in $\mathrm{Ca}^{+2}$ - and $\mathrm{Mg}^{+2}$-free, phosphatebuffered saline (PBS) $(\mathrm{NaCl} 137 \mathrm{mM} ; \mathrm{KCl} 2.7 \mathrm{mM}$; $\mathrm{Na}_{2} \mathrm{HPO}_{4} 3.9 \mathrm{mM} ; \mathrm{KH}_{2} \mathrm{PO}_{4} 1.8 \mathrm{mM}, \mathrm{pH} 7.4$ ) and administrated intraperitonially (i.p.) at a final concentration of $50 \mathrm{mg} / \mathrm{kg}$ of body weight (b.w.).

\section{Extraction and preparation of $\beta$-glucan}

The $\beta$-glucan molecules tested in this study were extracted from Saccharomyces cerevisiae. All methods for extraction and preparation of $\beta$-glucan were done according to the protocol of Oliveira et al. (2013). Solutions of $\beta$-glucan were prepared in sterile $\mathrm{Ca}^{+2}$ - and $\mathrm{Mg}^{+2}$-free PBS ( $\mathrm{NaCl} 137 \mathrm{mM} ; \mathrm{KCl} 2.7 \mathrm{mM} ; \mathrm{Na}_{2} \mathrm{HPO}_{4} 3.9 \mathrm{mM} ; \mathrm{KH}_{2} \mathrm{PO}_{4}$ $1.8 \mathrm{mM}, \mathrm{pH} 7.4)$ at concentrations of 100,150 and $200 \mathrm{mg} / \mathrm{kg}$ (b.w.). The doses were chosen according to Oliveira et al. (2013).

\section{Animals}

Male Swiss mice (Mus musculus) at reproductive age and with $30 \mathrm{~g}$ average weight were obtained from the Central Vivarium of the State University of Londrina. The experiment was performed at the Sectorial Vivarium of the Department of General Biology. The animals were kept isolated in a polypropylene box, and they had a minimum of seven days for adaptation. Light incidence (12 hours of light: 12 hours of darkness) and temperature $\left(22 \pm 2{ }^{\circ} \mathrm{C}\right)$ were controlled. Filtered water and commercial food pellets were provided ad libitum and the animals were inspected daily. At the end of the experiment, the animals were euthanized by cervical dislocation as the use of any anesthetic could interfere with the effects of the chemical compounds under investigation. All procedures and protocols followed approved guidelines for the ethical treatment of animals, according to the Ethics Committee in Animal Experimentation from the State University of Londrina (Protocol \# 30877/04).

\section{Experimental design and analysis methods}

The animals were randomly divided into eight experimental groups $(\mathrm{n}=6$ each) as follows: animals from the control group (Group 01) received sterile $\mathrm{Ca}^{+2}$ - and $\mathrm{Mg}^{+2}$ free PBS at a volume of $0.1 \mathrm{~mL} / 10 \mathrm{~g}$ (b.w.; i.p.) during three consecutive days. Animals of the cyclophosphamide group (Group 02) received this chemotherapy at the concentration of $50 \mathrm{mg} / \mathrm{kg}$ (b.w.; i.p.) on the second day of treatment and PBS during following days. For mutagenicity evaluation, Groups $03-05$ received $\beta$-glucan (i.p.) for 3 consecutive days, at the doses of 100,150 and $200 \mathrm{mg} / \mathrm{kg}$ (b.w.), respectively. For antimutagenicity evaluation, Groups $06-08$ received $\beta$-glucan (i.p.) for 3 consecutive 
days at the doses mentioned before and one dose of cyclophosphamide on the second day of treatment (Oliveira et al., 2013).

Peripheral blood was sampled from the experimental groups by puncturing the tail vein at three different time points to evaluate the mutagenic and/or antimutagenic potential by means of micronucleus testing in peripheral blood. Blood sample designated as time points T0 and T1 were always taken before the administration of treatment, within intervals of 24 hours. Time point T2 corresponds to a blood sample taken at 24 hours after the last administration of cyclophosphamide. This experimental design is complementary to the one proposed by Oliveira et al. (2013).

Animals were treated during three consecutive days per week, for six consecutive weeks. Blood samples were taken in the first, fifth and sixth week.

\subsection{Micronucleus assay in peripheral blood}

The micronucleus assay was originally described by Hayashi et al. (1990), with certain changes proposed by Oliveira et al. (2009a). The slides were warmed to $70{ }^{\circ} \mathrm{C}$ and covered with a layer of $20 \mu \mathrm{L}$ of Acridine Orange in an aqueous solution $(1.0 \mathrm{mg} / \mathrm{mL})$. After the preparation of the slides, a drop of peripheral blood was deposited on the slide and covered with a coverslip. Analyses were performed with a fluorescence microscope (Bioval ${ }^{\circledR}$ ) at $40 \mathrm{X}$ magnification, with a $420-490 \mathrm{~nm}$ excitation and a $520 \mathrm{~nm}$ barrier filter. A total of 2,000 cells were analyzed per animal.

\section{Dominant lethal assay}

Animals of different groups were treated for five weeks and then paired with two nulliparous and untreated females. The animals remained together to mate for a period of five days to ensure that the females reached the estrous cycle in the presence of treated male mice. Pregnancy was determined by the detection of a vaginal plug, and this was considered day zero of gestation. Females were submitted to laparotomy after 18 days of pregnancy to evaluate the fertility rate (number of pregnant females $\mathrm{x}$ $100 /$ number of females), number of implants, postimplantation loss rate (number of implants - number of live fetuses x 100 / number of implants), rate of reabsorption or frequency of lethal dominant (number of resorptions x 100 / number of implants) and collection of placentas and fetuses. Placentas were weighed and fetuses were weighed and measured. With these data, the placenta index was calculated (placental weight / fetal weight). The fetuses were classified as fetuses of adequate weight for gestational age (AWGA - weighing between the average weight of fetuses in the control group \pm standard deviation); fetuses of low weight for gestational age (LWGA - b.w. below the standard deviation's lower limit of the control fetuses' mean weight) and high weight's fetuses for gestational age (HWGA - b.w. above the standard deviation's upper limit of the control fetuses' mean weight), according to Oliveira et al. (2009).

\section{Calculation of the damage reduction percentage}

The cyclophosphamide damage reduction percentage (DR\%) by $\beta$-glucan administration was calculated as the mean of Group 2 minus the mean of an associated group (Groups 6-8) divided by the mean of Group 2 minus the mean of Group 1. The result was multiplied by 100 and expressed as DR\% (Manoharan and Banerjee, 1985; Waters et al., 1990).

\section{Statistical analysis}

The comparison of quantitative results was carried out using parametric and non-parametric tests (ANOVA/Tukey, Kruskal-Wallis/Dunn, unpaired Student's t-test and Chi-square), depending on the nature of the data distribution. In all cases, differences with $\mathrm{p}<0.05$ were considered statistically significant (Oliveira et al., 2009a, 2013).

\section{Results}

Table 1 reports parameters related to fertility and fetal development. The statistical analysis showed that there were no significant differences between experimental groups for the fertility parameter. Similarly, no differences were found for the number of implants and fetal viability. Upon analyzing the rate of reabsorption, a higher incidence was found in the group treated with cyclophosphamide and in the association group of cyclophosphamide and $\beta$-glucan in highest concentration. Fetal analysis showed that the treatments did not affect the intra-uterine development, as there were no changes in fetal length, fetal weight, placental weight, placental index. Furthermore, the weight to gestational age relationship was adequate and no external malformations were seen.

Tables 2 to 4 shows the frequency, average, standard deviation and $\mathrm{DR} \%$ for the micronucleus assay in peripheral blood cells. In the first week of treatment, at T0, all animals had the same frequency of micronuclei. The analysis of mutagenicity, assessed at T2, showed that $\beta$-glucan presented no mutagenic activity. Antimutagenic activity could be seen at T2, as a prevention of mutagenic damage in somatic cells could be denoted for the three different doses of $\beta$-glucan tested. The DR\%s were 95.08, 116.32 and $80.63 \%$ for the doses of 100,150 and $200 \mathrm{mg} / \mathrm{kg}$, respectively.

During the fifth week of treatment all groups had the same baseline frequency of micronuclei. At T2, $\beta$-glucan did not show mutagenic activity and only the higher dose was chemopreventive $(\mathrm{p}<0.05)$. The $\mathrm{DR} \%$ s were 10.72 , 10.20 and $52.54 \%$ for the doses of 100,150 and $200 \mathrm{mg} / \mathrm{kg}$, respectively. 


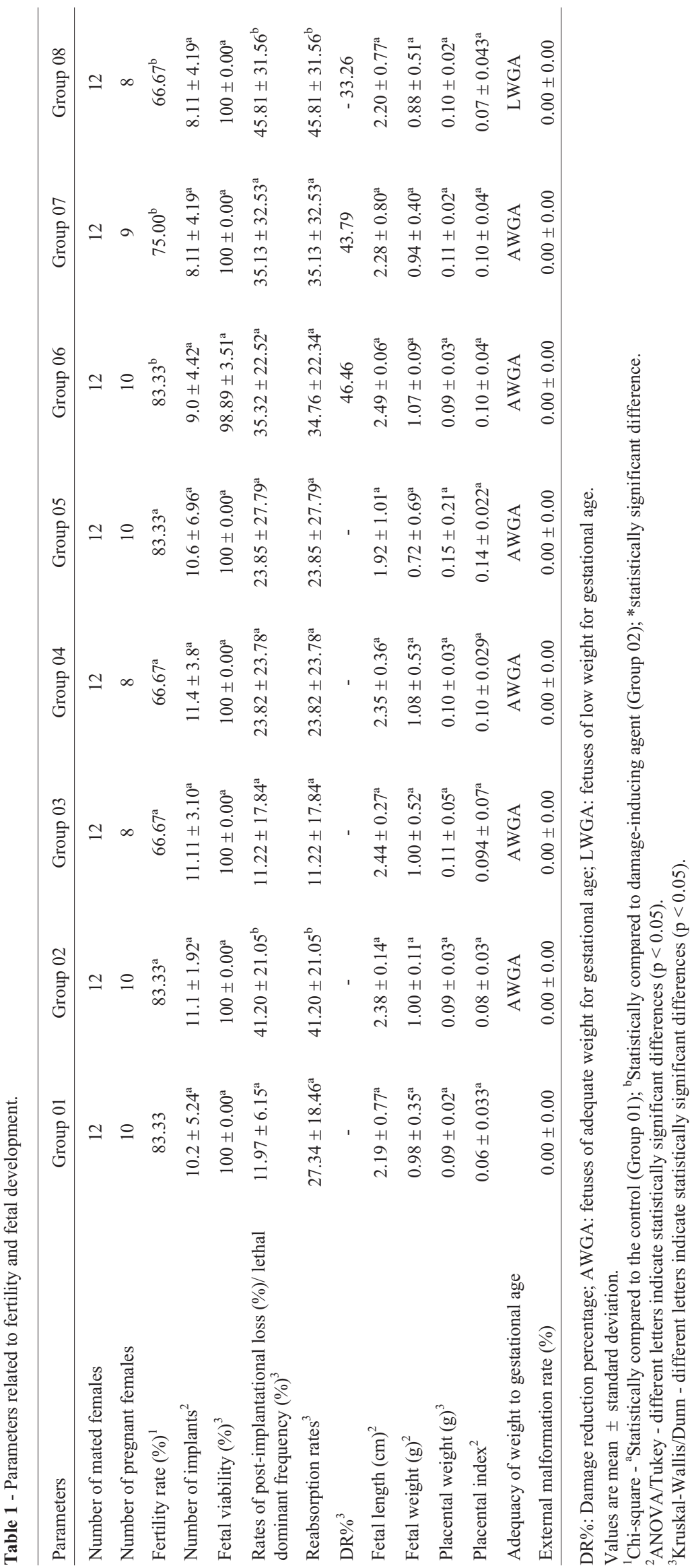


Table 2 - Frequency, mean \pm SD and DR\% for the micronucleus assay done on peripheral blood cells during the first week of treatment.

\begin{tabular}{|c|c|c|c|c|c|c|c|}
\hline \multirow[t]{2}{*}{ Treatment } & \multicolumn{3}{|c|}{ Micronuclei frequency } & \multicolumn{3}{|c|}{ Mean \pm SD } & \multirow{2}{*}{$\begin{array}{c}\mathrm{DR} \% \\
\mathrm{~T} 2\end{array}$} \\
\hline & $\mathrm{T} 0$ & $\mathrm{~T} 1$ & $\mathrm{~T} 2$ & T0 & $\mathrm{T} 1$ & $\mathrm{~T} 2$ & \\
\hline Group 01 & 49 & 33 & 56 & $8.17 \pm 2.71$ & $5.50 \pm 2.81$ & $9.33 \pm 1.97$ & - \\
\hline Group 02 & 33 & 36 & 117 & $5.50 \pm 2.07^{\mathrm{a}}$ & $6.00 \pm 2.28^{\mathrm{a}}$ & $19.5 \pm 4.08^{\mathrm{a}^{*}}$ & - \\
\hline \multicolumn{8}{|c|}{ Mutagenicity } \\
\hline Group 03 & 42 & 40 & 44 & $7.00 \pm 2.97^{\mathrm{a}}$ & $6.67 \pm 1.63^{\mathrm{a}}$ & $7.33 \pm 4.80^{\mathrm{a}}$ & - \\
\hline Group 04 & 35 & 53 & 54 & $5.83 \pm 3.66^{\mathrm{a}}$ & $8.83 \pm 4.02^{\mathrm{a}}$ & $9.00 \pm 3.74^{\mathrm{a}}$ & - \\
\hline Group 05 & 41 & 36 & 44 & $6.83 \pm 2.64^{\mathrm{a}}$ & $6.00 \pm 3.74^{\mathrm{a}}$ & $7.33 \pm 2.25^{\mathrm{a}}$ & - \\
\hline \multicolumn{8}{|c|}{ Antimutagenicity } \\
\hline Group 06 & 37 & 20 & 59 & $6.17 \pm 2.48^{\mathrm{b}}$ & $3.33 \pm 1.75^{\mathrm{b} *}$ & $9.83 \pm 1.72^{\mathrm{b}^{*}}$ & 95.08 \\
\hline Group 07 & 30 & 26 & 46 & $5.00 \pm 2.37^{\mathrm{b}}$ & $4.33 \pm 2.25^{\mathrm{b}}$ & $7.67 \pm 4.37^{b^{*}}$ & 116.32 \\
\hline Group 08 & 32 & 35 & 68 & $5.33 \pm 2.42^{\mathrm{b}}$ & $5.83 \pm 3.71^{\mathrm{b}}$ & $11.3 \pm 5.01^{\mathrm{b}^{*}}$ & 80.63 \\
\hline
\end{tabular}

SD: Standard deviation; DR\%: Damage reduction percentage. ${ }^{a}$ Statistically compared to the control (Group 01). ${ }^{\text {b }}$ Statistically compared to the damage-inducing agent (Group 02). *statistically significant difference (unpaired Student's t-test, p < 0.05). Time points T0, T1 and T2: samples of blood taken within interval of 24 hours.

Table 3 - Frequency, mean \pm SD and DR\% for the micronucleus assay done on peripheral blood cells during the fifth week of treatment.

\begin{tabular}{|c|c|c|c|c|c|c|c|}
\hline \multirow[t]{2}{*}{ Treatment } & \multicolumn{3}{|c|}{ Micronuclei frequency } & \multicolumn{3}{|c|}{ Mean \pm SD } & \multirow{2}{*}{$\begin{array}{c}\mathrm{DR} \% \\
\mathrm{~T} 2\end{array}$} \\
\hline & T0 & $\mathrm{T} 1$ & $\mathrm{~T} 2$ & T0 & $\mathrm{T} 1$ & $\mathrm{~T} 2$ & \\
\hline Group 01 & 55 & 52 & 76 & $9.17 \pm 3.82$ & $8.67 \pm 6.19$ & $12.67 \pm 4.97$ & - \\
\hline Group 02 & 70 & 55 & 272 & $11.7 \pm 2.25^{\mathrm{a}}$ & $9.17 \pm 2.93^{\mathrm{a}}$ & $45.33 \pm 16.03^{\mathrm{a}^{*}}$ & - \\
\hline \multicolumn{8}{|c|}{ Mutagenicity } \\
\hline Group 03 & 36 & 52 & 76 & $6.00 \pm 3.10^{\mathrm{a}}$ & $8.67 \pm 5.28^{\mathrm{a}}$ & $12.67 \pm 8.57^{\mathrm{a}}$ & - \\
\hline Group 04 & 55 & 42 & 52 & $9.17 \pm 5.23^{\mathrm{a}}$ & $7.00 \pm 3.46^{\mathrm{a}}$ & $8.67 \pm 2.80^{\mathrm{a}}$ & - \\
\hline Group 05 & 36 & 91 & 74 & $6.00 \pm 3.63^{\mathrm{a}}$ & $15.17 \pm 8.95^{\mathrm{a}}$ & $12.33 \pm 5.32^{\mathrm{a}}$ & - \\
\hline \multicolumn{8}{|c|}{ Antimutagenicity } \\
\hline Group 06 & 56 & 46 & 251 & $9.33 \pm 5.64^{\mathrm{b}}$ & $7.67 \pm 2.80^{\mathrm{b}}$ & $41.83 \pm 18.60^{\mathrm{b} *}$ & 10.72 \\
\hline Group 07 & 39 & 40 & 252 & $6.50 \pm 5.64^{b^{*}}$ & $6.67 \pm 4.46^{\mathrm{b}}$ & $42.00 \pm 12.38^{\mathrm{b}^{*}}$ & 10.20 \\
\hline Group 08 & 55 & 52 & 169 & $9.17 \pm 4.35^{\mathrm{b}}$ & $8.67 \pm 4.13^{\mathrm{b}}$ & $28.17 \pm 11.14^{\mathrm{b}^{*}}$ & 52.54 \\
\hline
\end{tabular}

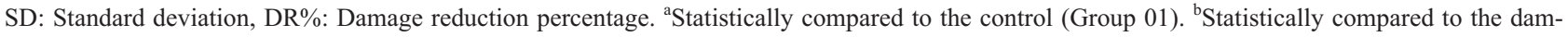
age-inducing agent (Group 02). *Statistically significant difference (unpaired Student's t-test, $p<0.05$ ). Time points T0, T1 and T2: samples of blood taken within interval of 24 hours.

Analysis of the sixth week of treatment showed that $\beta$-glucan did not exert a mutagenic effect. However, groups 02, 06, 07 and 08 (which received cyclophosphamide during the six weeks of treatment) showed very high frequencies of micronuclei (at least 3.6 times). The mutagenicity remained similar to the control at $\mathrm{T} 1$ and $\mathrm{T} 2$, indicating once again that $\beta$-glucan showed no mutagenic activity. In the assessment of $\mathrm{T} 1$ it was noticied that after administration of $\beta$-glucan there was a considerable reduction in damage relating to the ones present at $\mathrm{T} 0$. The evaluation of $\mathrm{T} 2$ indicated chemoprevention only for the two lower doses and the respective $\mathrm{DR} \%$ s were $62.35,39.87$ and $-0.95 \%$ for the doses of 100, 150 and $200 \mathrm{mg} / \mathrm{kg}$ (Figure 1).

\section{Discussion}

Several reports indicate $\beta$-glucan chemoprevention activity in vitro (Slamenová et al., 2003; Oliveira et al., 2006, 2007; Angeli et al., 2006, 2009a,b; Mantovani et al., 2008; Silva et al., 2013), including molecular level treatments (Da Silva et al., 2013), in vivo (Chorvatovicová et al., 1996, 1998; Tohamy et al., 2003; Lin et al., 2004; Mantovani et al., 2008; Oliveira et al., 2009., 2013) and recently also in humans (Magnani et al., 2011). These results suggest that $\beta$-glucan is potentially useful in improving short-term survival. However the literature is scarce when it comes to studying the influence of this polysaccharide in 
Table 4 - Frequency, mean \pm SD and DR\% for the micronucleus assay done on peripheral blood cells during the sixth week of treatment.

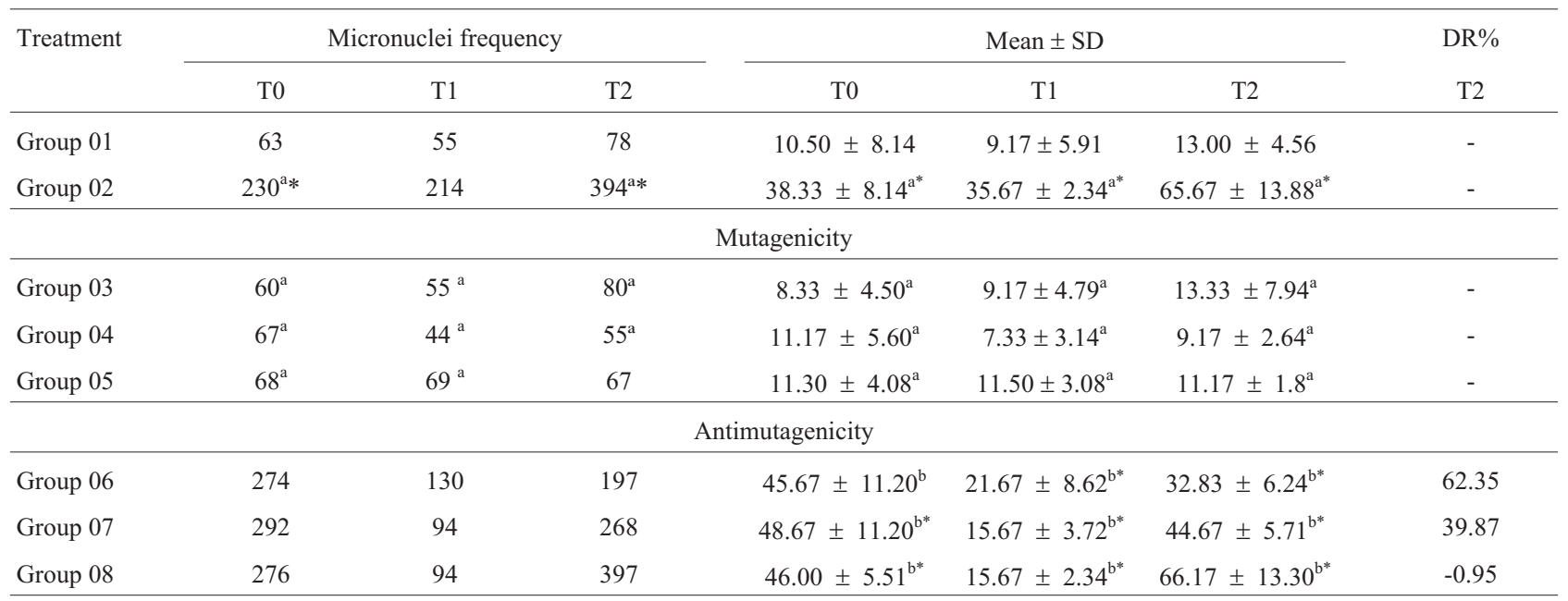

SD: Standard deviation; DR\%: Damage reduction percentage. ${ }^{\text {a }}$ Statistically compared to the control (Group 01). ${ }^{\mathrm{b}}$ Statistically compared to the damage-inducing agent (Group 02). *statistically significant difference (unpaired Student's t-test, p < 0.05). Time points T0, T1 and T2: samples of blood taken within interval of 24 hours.

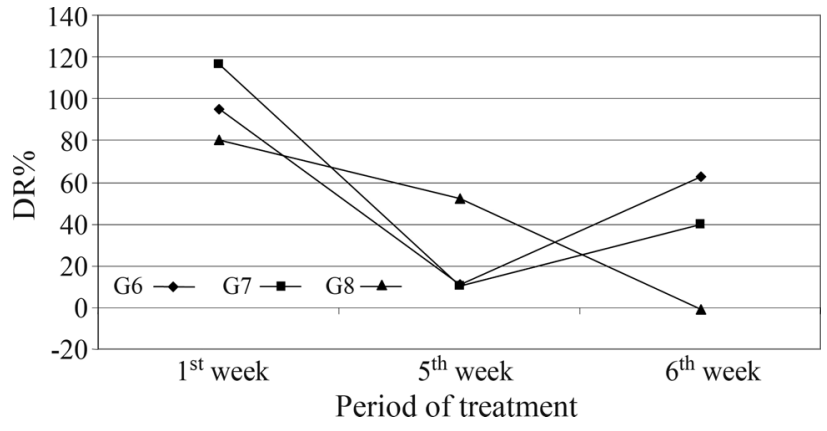

Figure 1 - Antimutagenic behavior of the $\beta$-glucan molecule measured by $\mathrm{DR} \%$ in the micronucleus assay.

maintaining the reproductive performance of males and females and fertility of experimental animals exposed to gonadotoxic agents such as cyclophosphamide. Another fact that draws attention is that there are no studies to assess the effectiveness of $\beta$-glucan over several weeks in acute multiple dose protocols associated with male reproductive performance. In this sense, the current study represents pioneering research.

We did not observe any changes in fertility rate, number of implants and fetal viability. However, the rate of reabsorption was higher in the group receiving cyclophosphamide in association to $\beta$-glucan at the highest concentration. Analysis of the rate of post-implantation losses is also known as the dominant lethal assay (Degraeve et al., 1985; Morrissey et al., 1990).

The presented results show that the dose of cyclophosphamide used did not reduce the fertility of animals and also did not affect the number of implants and fetal viability. However, cyclophosphamide caused changes in the development of implanted embryos, frequently leading to death. Analysis of the rates of post-implantation loss and resorption are complementary data to this conclusion. Thus, it appears that $\beta$-glucan was able to reduce the rates of post-implantation losses and reabsorption when used in the two lower doses, therefore suggesting that it is efficient in preventing genetic damage in germ cells. Moreover, embryos without dominant lethal mutations had an appropriate intrauterine growth and corroborate to this the parameters of fetal length, fetal weight, adequacy of weight to gestational age, placental weight and placental index.

When it comes to the validation of the dominant lethal assay, there is a need to consider that the embryonic or fetal deaths must be understood as resulting from a dominant lethal mutation that occurred and was transmitted to the offspring by DNA via the sperm. Thus, the basis for the use of dominant lethals is that zygotic embryonic or fetal deaths occur due to changes or chromosomal rearrangements. Evidence for this comes from cytogenetic analysis performed on embryo samples (Maxwell and Newell, 1973).

Overall, the conclusion is that the doses of $\beta$-glucan administered did not cause any changes in the evaluated reproductive parameters. Furhtermore, cyclophosphamide at the administered dose resulted in an increase in rates of post-implantation loss and reabsorption, but when associated with $\beta$-glucan, a decrease in the reabsorption rate and an improvement in reproductive performance was observed. Herein, the two lower doses tested had very similar efficiency while the highest dose did not contribute to the prevention of such damage.

According to Tohamy et al. (2003) the protocol of pre-treatment with $\beta$-glucan $100 \mathrm{mg} / \mathrm{kg}$ (b.w.; i.p.) tested in mice that received $2.5 \mathrm{mg} / \mathrm{kg}$ (b.w.) of cyclophosphamide, $12 \mathrm{mg} / \mathrm{kg}$ (b.w.) of adriamycin, and $5 \mathrm{mg} / \mathrm{kg}$ (b.w.) of 
cisplatin (i.p.) showed a DR\% of $47.11,28.5$ and $69.15 \%$ of chromosomal aberrations in bone marrow cells for cyclophosphamide, adriamycin and cisplatin respectively. In spermatogonia, these were $49.44,67.33$ and $69.20 \%$ for cyclophosphamide, adriamycin and cisplatin respectively. Thus, this data indicates that the polysaccharide has chemopreventive capacity in both somatic and germ cells. Notwithstanding, despite using different tests, our study supports the data from Tohamy et al. (2003), since both indicate DR\%s in germ cells, except for the higher dose of $\beta$-glucan.

The micronucleus assay is often used to evaluate the organisms exposure to chemical or physical agents (Tucker and Preston, 1996), being an important procedure in genetic toxicology and when evaluating the carcinogenic potential of compounds (Krishna and Hayashi 2000). According to Kishi et al. (1992), comparative studies between the conventional technique in bone marrow stained by Giemsa and the technique that uses pre-staining with Acridine Orange show a good correlation. Thus, we opted for the Acridine Orange pre-staining. With peripheral blood cells, this technique has an advantage as each animal can provide multiple samples without the need of euthanasia (CSGMT, 1992).

We observed that in the first week of treatment, $\beta$-glucan did not cause changes in micronucleus frequency and that all $\beta$-glucan doses were chemopreventive, as there was a decrease in the frequency of micronuclei in the treatment group. In the fifth week, $\beta$-glucan alone also did not result in an increased micronucleus frequency, but when associated with cyclophosphamide there was a drastic reduction in the chemopreventive capacity of the $\beta$-glucan. It is worthy of note that the highest dose of $\beta$-glucan in the first week had the lowest DR\%. However, during the fifth week, this same dose was the only one that showed a statistically significant difference in DR\%.

For the sixth week of treatment, at $\mathrm{T} 0$ all animals that had received cyclophosphamide in the weeks before showed 3.6 times higher micronucleus frequency than the control. Compared to the groups where $\beta$-glucan was associated with the damage-inducing agent, the group which received the lowest dose, group 6, started out with a similar number of micronuclei $(p>0.05)$. However, groups 7 and 8 which received the middle and highest doses of $\beta$-glucan had significantly higher frequencies $(p<0.05)$. After administration of $\beta$-glucan there was considerable decrease in the frequency of micronuclei for the two lower doses. For the highest dose there was no damage reduction.

When assessing the behavior of the three doses used during the experimental weeks, we found that in the first week of treatment all doses had a good chemopreventive activity, and the middle dose gave the best results, followed by the lower and higher dose, respectively. Yet, in the fifth week, the situation had changed because only the higher dose presented chemopreventive capacity. For the sixth week, we noted again that only the lower and middle doses presented chemopreventive capacity. Thus, in this study a dose-response relationship was not established. These results are similar to what we observed in previous in vitro and in vivo studies (Oliveira et al., 2006, 2007, 2009) and also are in agreement with the findings of a multiple doses protocol (Oliveira et al., 2013) showing that in the first week of treatment $\beta$-glucan presented DR\%s between $62.04-100.00 \%$ and $59.52-94.34 \%$ for mutagenic and genotoxic damages, respectively. This activity decreased as the treatment was extended. During the sixth week of treatment, antimutagenicity rates were reduced to 39.83$59.51 \%$ and no antigenotoxicity effect was seen.

For several years now the polysaccharide $\beta$-glucan has being tested for its chemopreventive ability. Patchen et al. (1987) showed that it improves survival of animals treated with radiation, and that this improvement is due not only to hematopoietic regeneration, but the authors also assume that $\beta$-glucan is able to inactivate free radicals that could cause damage to the body Chorvatovicová (1991) also suggested that the polysaccharide acts as an antioxidant. However, only in 2006 the antimutagenic mode of action of $\beta$-glucan extracted from barley was described (Oliveira et al., 2006), reporting that $\beta$-glucan has desmutagenenic and bioantimutagenic activity. Thus, there is evidence that $\beta$-glucan can act by intercepting agents that cause damage to the DNA while they are still in the extracellular environment, or act as an antioxidant capable of modulating the DNA repair system in the intracellular environment. A study with $\beta$-glucan extracted from Saccharomyces cerevisiae confirmed that $\beta$-glucan has desmutagenic and bioantimutagenic activity (Oliveira et al., 2007). The protocols established in the current study were based upon the $\beta$-glucan modes of action described previously. Thus, an administration of $\beta$-glucan prior to that of cyclophosphamide, one concomitantly and another thereafter were used to obtain a maximal capacity of $\beta$-glucan chemopreventive ability, and the data suggest chemoprevention to both somatic and germ cells. Also, corroborate findings on the decrease in the rates of reabsorption and post-implantation losses. This study is also in accordance with data from Morrissey et al. (1990) showing a correlation with mutagenic events in somatic cells.

An important aspect in the analysis of reproductive performance is sperm morphology, and current results show an increase in exchanges between sister chromatids leading to the increase in the frequency of dominant lethal mutations and decreased sperm quality. McGregor (1984) also strengthens the relationship between changes in sperm head morphology and the increasing in frequency in occurrence of dominant lethal mutations.

It is thus feasible that in the near future $\beta$-glucan may be used as an effective chemopreventive agent being able to 
modulate changes that affect both the individual and its offspring. Some studies already suggest the consumption of $\beta$-glucan for injury prevention in genomic somatic and germ cells. The current study underlines the effectiveness of this chemopreventive polysaccharide, but this chemoprevention is not consistent in multiple doses treatment. Further studies are thus still clearly needed to firmly establish the mode of action of $\beta$-glucan as well its indication or contra-indication in chemoprevention and/or for preventing alterations in reproductive performance, embryo-fetal development and genomic integrity of germ cells.

\section{Acknowledgments}

This study was funded by Conselho Nacional de Desenvolvimento Científico e Tecnológico (CNPq), Coordenadoria de Aperfeiçoamento de Nível Superior (CAPES) and Fundação Araucária.

\section{References}

Anderson D (2005) Male-mediated developmental toxicity. Toxicol Appl Pharm 207:506-513.

Angeli JP, Ribeiro LR, Gonzaga ML, Soares S de A, Ricardo MP, Tsuboy MS, Stidl R, Knasmueller S, Linhares RE and Mantovani MS (2006) Protective effects of beta-glucan extracted from Agaricus blazei against chemically induced DNA damage in human lymphocytes. Cell Biol Toxicol 22:285-291.

Angeli JP, Ribeiro LR, Angeli JL and Mantovani MS (2009a) Protective effects of beta-glucan from barley against benzo[a]pyrene-induced DNA damage in hepatic cell HepG2. Exp Toxicol Pathol 61:83-89.

Angeli JP, Ribeiro LR, Bellini MF and Mantovani MS (2009b) Beta-glucan extracted from the medicinal mushroom Agaricus blazei prevents the genotoxic effects of benzo[a]pyrene in the human hepatoma cel line HepG2. Arch Toxicol 83:81-86.

Chorvatovicová D (1991) Suppressing effects of glucan on micromuceli induced by Co60 in mice, Strahlenther Onkol 167:612-614.

Chorvatovicová D, Machová E and Sandula J (1996) Effect of ultrasonicated carboxymethylglucan on cyclophosphamide induced mutagenicity. Mutat Res 371:115-120.

Chorvatovicová D, Machová E and Sandula J (1998) Ultrasonication: The way to achieve antimutagenic effect of carboxymethyl-chitin-glucan by oral administration. Mutat Res 412:83-89.

Cordier S, Monfort C, Filippini G, Preston-Martin S, Lubin F, Mueller BA, Holly EA, Peris-Bonet R, McCredie M, Choi $\mathrm{W}$, et al. (2004) Parental exposure to polycyclic aromatic hydrocarbons and the risk of childhood brain tumors: The SEARCH International Childhood Brain Tumor Study. Am J Epidemiol 159:1109-1116.

CSGMT - Collaborative Study Group for the Micronucleus Test (1992) Micronucleus test with mouse peripheral blood erythrocytes by acridine orange supravital staining: The summary report of the 5th collaborative study by CSGMT/JEMS.MMS. Mutat Res 278:83-98.

Da Silva AF, Sartori D, Macedo Jr FC, Ribeiro LR, Fungaro MHP and Mantovani MS (2013) Effects of b-glucan extracted from Agaricus blazei on the expression of ERCC5, CASP9, and CYP1A1 genes and metabolic profile in HepG2 cells. Hum Exp Toxicol 32:647-654.

De Cherney AH (1987) Infertilidade: Princípios gerais da avaliação. In: Kase NG and Weingold $\mathrm{AB}$ (eds) Ginecologia Clínica. Guanabara, Rio de Janeiro, pp 313-321.

Degraeve N, Chollet MC and Moutschen J (1985) Mutagenic efficiency of organophosphorus insecticides used in combined treatments. Environ Health Perspect 60:395-398.

Di Luzio NR, Williams DL, Mcnamee RB, Edwards BF and Kitahama A (1979) Comparative tumor-innhibitory and anti-bacterial activity of soluble and particulate glucana. Int J Cancer 24:773-779.

Ferrari AN (1991) Esterilidade Conjugal. Ferrari AN (ed). Roca, São Paulo, 434 pp.

Friedler G (1996) Paternal exposures: Impact on reproductive and developmental outcome: An overview. Pharmacol Biochem Behav 55:691-700.

Hayashi M, Morita T, Kodama Y, Sofuni T and Ishidate Jr M (1990) The micronucleus assay with mouse peripheral blood reticulocytes using acrideine orange-coated slides. Mutat Res 245:245-249.

Jenkinson PC, Anderson D and Gangolli SD (1987) Increased incidence of abnormal foetuses in the offspring of cyclophosphamide and allyl alcohol-treated male mice. Mutat Res 188:57-62.

Jenkinson PC and Anderson D (1990) Malformed foetuses and karyotype abnormalities in the offspring of cyclophosphamide and allyl alcoholtreated male rats. Mutat Res 229:173184.

Ji BT, Shu XO, Linet MS, Zheng W, Wacholder S, Gao YT, Ying DM and Jin F (1997) Paternal cigarette smoking and the risk of childhood cancer among offspring of nonsmoking mothers. J Natl Cancer Inst 89:238-244.

Joffe JM and Soyka LF (1984) Paternal drug exposure: Effects on reproduction and progeny. Sem Perinat 6:116-124.

Kishi M, Horiguchi Y, Watanabe S and Hayashi M (1992) Validation of the mouse peripheral blood micronucleus assay using acridine orange supravital staining with urethane. Mutat Res 278:205-208.

Krishna G and Hayashi M (2000) In vivo rodent micronucleus assay: Protocol, conduct and data interpretation. Mutat Res 455:155-166.

Lin H, She Y, Cassileth B, Sirotnak F and Rundles SC (2004) Maitake beta-glucan MD-fraction enhances bone marrow colony formation and reduces doxorubicin toxicity in vitro. Int Immunopharmacol 4:91-99.

Lipshultz LI and Fisch H (1992) Diagnosing male factors of infertity. Arch Pathol Lab Med 116:398-405.

Magnani M, Castro-Gomez RJH, Mori MP, Kyasne H, Gregório EP, Libos-Jr F and Cólus IMS (2011) Protective effect of carboxymethyl-glucan (CM-G) against DNA damage in patients with advanced prostate cancer. Genet Mol Biol 34:131-135.

Manoharan K and Banerjee MR (1985) beta-Carotene reduces sister chromatid exchanges induced by chemical carcinogens in mouse mammary cells in organ culture. Cell Biol Int Rep 9:783-789.

Mantovani MS, Bellini MF, Angeli JP, Oliveira RJ, Silva AF and Ribeiro LR (2008) Beta-glucan in promoting health: Prevention against mutation and cancer. Mutat Res 658:154-161. 
Mauro MO, Monreal MTFD, Silva MTP, Pesarini JR, Mantovani MS, Ribeiro LR, Carreira CR, Dichi JB and Oliveira RJ (2013) Evaluation of the antimutagenic and anticarcinogenic effects of inulin in vivo. Genet Mol Res 12:22812293.

Maxwell WA and Newell GW (1973) Considerations for evaluating chemical mutagenicity to germinal cells. Environ Health Perspect 6:47-50.

McGregor DB (1984) Genotoxicity of glycol ethers. Environ Health Perspect 57:97-103.

Morrissey RE, Fowler BA, Harris MW, Moorman MP, Jameson CW and Schwetz BA (1990) Arsine: Absence of developmental toxicity in rats and mice. Fundam Appl Toxicol 15:350-356.

Oliveira RJ, Oliva SU, Daroz GA and Rúbio EM (2005) Avaliação da fertilidade e de possíveis defeitos estruturais externos sobre a prole de ratos machos expostos cronicamente ao arsênio. Rev Brasil Toxicol 18:57-61.

Oliveira RJ, Ribeiro LR, Silva AF, Matuo R and Mantovani MS (2006) Evaluation of antimutagenic activity and mechanisms o action of beta-glucan from barley, in CHO-k1 and HTC cell lines using the micronucleus test. Toxicol in Vitro 20:1225-1233.

Oliveira RJ, Matuo R, Silva AF, Matiazi HJ, Mantovani MS and Ribeiro LR (2007) Protective effect of beta-glucan extracted from Saccharomyces cerevisiae, against DNA damage and cytotoxicity in wild-type (k1) and repair-deficient (xrs5) CHO cells. Toxicol in Vitro 21:41-52.

Oliveira RJ, Baise E, Mauro MO, Pesarini JR, Matuo R, Silva AF, Ribeiro LR and Mantovani MS (2009a) Evaluation of chemopreventive activity of glutamine by the comet and the micronucleus assay in mice's peripheral blood. Environ Toxicol Pharmacol 28:120-124.

Oliveira RJ, Faria MJSS, Silva AF, Kanno TYN, Lourenço ACS, Freiria GA, Matiazi HJ, Ribeiro LR and Mantovani MS (2009b) Effects of the polysaccharide $\beta$-glucan on clastogenicity and teratogenicity caused by acute exposure to cyclophosphamide in mice. Regul Toxicol Pharmacol 53:164-173.

Oliveira RJ, Salles MJS, Silva AF, Kanno TYN, Lourenço ACS, Leita VS, Matiazi HJ, Pesarini JR, Ribeiro LR and Mantovani MS (2013). In vivo evaluation of the antimutagenic and antigenotoxic effects of $\beta$-glucan extracted from Saccharomyces cerevisiae in acute treatment with multiple doses. Genet Mol Biol 36:413-424.

Orejuela F and Lipshultz LI (1998) The effect of working environment on male reproductive health. Contemp Urol 10:86-93.

Pang D, McNally R and Birch JM (2003) Parental smoking and childhood cancer: Results from the United Kingdom Childhood Cancer Study. Br J Cancer 88:373-381.

Patchen ML, D'Alesandro MM, Brook I, Blakely WF and Mac Vittie TJ (1987) Glucan: Mechanisms involved in its radioprotective effect. J Leukocyte Biol 42:95-105.

Pesarini JR, Zaninetti PT, Mauro MO, Carreira CM, Dichi JB, Ribeiro LR, Mantovani MS and Oliveira RJ (2013) Anti- mutagenic and anticarcinogenic effects of wheat bran in vivo. Genet Mol Res 12:1646-1659.

Sadi MV (1995) Função testicular. In: Lima GR and Baracat EC (eds) Ginecologia Endócrina. Ateneu, São Paulo, pp 75-81.

Sarkar M, Gangopadhyay P, Basak B, Chakrabarty K, Banerji J, Adhikary P and Chatterjee A (2000) The reversible antifertility effect of Piper betle Linn on Swiss albino male mice. Contraception 62:271-274.

Shively CA, White DM, Blauch JL and Tarka Jr SM (1984) Dominant lethal testing of theobromine in rats. Toxicol Lett 20:325-329.

Silva AF, Oliveira RJ, Megumi NA, D’Epiro GFR, Ribeiro LR and Mantovani MS (2013) Anticlastogenic effect of $\beta$-glucan, extracted from Saccharomyces cerevisiae, on cultured cells exposed to ultraviolet radioation. Cytotechnology 65:41-48.

Slamenová D, Lábaj J, Krizková L, Kogan G, Sandula J, Bresgen $\mathrm{N}$ and Eclk P (2003) Protective effects of fungal $(1 \rightarrow 3)-\beta$ D-glucan derivatives against oxidative DNA lesions in V79 hamster lung cells. Cancer Lett 198:153-160.

Sorahan T, Prior P, Lancashire RJ, Faux SP, Hulten MA, Peck IM and Stewart IM (1997a) Childhood cancer and parental use of tobacco: Deaths from 1971 to 1976 . Br J Cancer 76:1525-1531.

Sorahan T, Lancashire RJ, Hulten MA, Peck I and Stewart AM (1997b) Childhood cancer and parental use of tobacco: Deaths from 1953 to 1955. Br J Cancer 75:124-138.

Sorahan T, McKinney PA, Mann JR, Lancashire RJ, Stiller CA, Birch JM, Dodd HE and Cartwright RA (2001) Childhood câncer and parental use of tobacco: Findings from the interregional epidemiological study of childhood cancer (IRESCC). Br J Cancer 84:141-146.

Thonneau P, Bujan L, Multigner L and Mieusset R (1998) Occupational heat exposure and male fertility: A review. Hum Reprod 13:2122-2125.

Tohamy AA, El-Ghor AA, El-Nahas SM and Noshy MM (2003) $\beta$-Glucan inhibits the genotoxicity of cyclophosphamide, adramycin and cisplatin. Mutat Res 541:45-53.

Tucker JD and Preston RJ (1996) Chromossome aberrations, micronuclei, aneuploidy, sister chromatid exchanges and cancer risk assessment. Mutat Res 365:147-159.

Van Thiel DH, Gavaler JS, Smith WI and Paul G (1979) Hypothalamic-pituitary-gonadal dysfunction in men using cimetidine. N Engl J Med 3:1012-1015.

Vested A, Ramlau-Hansen CH, Olsen SF, Bonde JP, Kristensen SL, Halldorsson TI, Becher G, Haug LS, Ernst EH and Toft $\mathrm{G}$ (2013) Associations of in utero exposure to perfluorinated alkyl acids with human semen quality and reproductive hormones in adult men. Environ Health Perspect 121:453-458.

Waters MD, Brady AL, Stack HF and Brockman HE (1990) Antimutagenicity profiles for some model compounds. Mutat Res 238:57-85.

\section{Associate Editor: Carlos R. Machado}

All the content of the journal, except where otherwise noted, is licensed under a Creative Commons License CC BY-NC. 